\title{
The 2017 Rohingya Crisis: A Corpus-Assisted Discourse Analysis of Representation in The Daily Star
}

\author{
Sharufatun Nahar
}

\begin{abstract}
There is a noteworthy lack of research on media coverage of refugees and other minority groups in South Asia. In comparison, research on Western media coverage is more common and well established. This imbalance can lead to our understanding of news media representation of these groups to be incomplete and limited. The aim of this study is to examine the in The Daily Star, a popular Bangladeshi news media. The corpus contains 406 online articles reporting the Rohingya issue, published on The Daily Star's website from August 2017 to August 2018. Multidisciplinary Corpus-assisted Discourse Analysis (CADS), a mixed method combining quantitative and qualitative techniques from Corpus Linguistics and Discourse Analysis, is utilized to analyze the data, informed by Mutua's (2001) work in critical human rights theory. Using the corpus analysis software AntConc 3.5.7 and Van Leeuwen's (1996, 2008) socio-semantic network model, collocations and concordances of key terms are explored in order to identify categories of representation and related discourses. Findings suggest that The Daily Star employs the savage-victim-savior (SVS) framework, typically found in dominant human rights literature, in constructing the main social actors of the crisis, namely the Rohingya, Bangladesh, and Myanmar. The Rohingya crisis is seen to be constructed as a humanitarian issue wherein the plight of the Rohingya is highlighted to construct them as victims. Bangladesh is constructed positively in processes of sheltering the Rohingya, while Myanmar is constructed negatively in processes of abusing the Rohingya. At the same time, the Rohingyas' repatriation is a salient topic of discussion. This work is intended to enrich studies on refugee and migration issues, besides adding to existing literature on the Rohingya.
\end{abstract}

Index Terms-Discourse analysis, news media, refugee, rohingya crisis, social actor.

\section{INTRODUCTION}

Discourse studies have examined refugee representation in media for decades, especially in the West, where research on RAS (refugees and asylum seekers) is abundant. Studies have found that RAS are represented most often as victims, homogenous out-groups, economic burdens, and security threats. Comparatively, studies in Asia are significantly fewer, considering Asia not only makes up around half of the world's refugee population, but also hosts the majority of this population [1]. For instance, Turkey has around 3 million Syrian refugees, Pakistan has around 1.5 million Afghan refugees, and Bangladesh currently has over 1 million Rohingya refugees. In fact, the UNHCR report claims that developing countries (in Asia and Africa) host $84 \%$ of the world's refugee population [1].

Manuscript received February 20, 2019; revised May 2, 2019.

Sharufatun Nahar is with the Faculty of Languages and Linguistics, University of Malaya, Jalan Universiti, 50603 Kuala Lumpur, Malaysia (e-mail: sharufanahar@gmail.com).
Discourse studies on refugees in Asia that have been done so far have found similar patterns repeated from Western representations of RAS. However, not enough attention has been given to the Rohingya, who are not only refugees, but stateless refugees due to not being recognized or accepted as legal citizens in Myanmar, where they claim citizenship.

This research intends to explore how the Rohingya are represented in media- more specifically, the media of a host county, Bangladesh, in the context of the Rohingya refugee crisis of 2017, during which over 600,000 Rohingya fled from Myanmar to Bangladesh between August and October alone. Since a well-rounded understanding of their representation warrants examination of the discourses involved, this research endeavors to analyze the representations of two other main social actors, Bangladesh and Myanmar, alongside that of the Rohingya, in order to facilitate this understanding.

I analyze online news reports in Bangladesh's most popular English language newspaper, The Daily Star, to explore how the three main social actors are represented in a year's span of coverage of the 2017 Rohingya crisis. I intend to see how representations compare with established Western media perspectives surrounding RAS and dominant human rights discourse, through a textual analysis that is guided by Mutua's SVS (savage-victim-savior) metaphor in critical human rights theory [2].

In the rest of the chapter, I provide some background on the Rohingya, Bangladesh, and The Daily Star to help the reader understand how they relate to the research and to each other. Following this, I present the research objective and research question.

\section{A. Who Are the Rohingya?}

The Rohingya are an ethnic and religious minority living mostly in the Rakhine State of Western Myanmar, adjacent to Bangladesh [3], [4]. Discrimination against the Rohingya in Buddhist majority Myanmar has often been documented by human rights groups, with reports describing a 'history of persecution' [5].

There are two views in Myanmar regarding the ancestry of the Rohingya. The dominant one holds that they settled in Myanmar in the $9^{\text {th }}$ century and are of mixed ancestry. The other view maintains that they are illegal migrants from Bangladesh [6], [7]. Myanmar's Government refuses to acknowledge the label 'Rohingya,' and calls them 'Bengali' instead, aiming to assert their illegality.

Periods of Rohingya migration to Bangladesh due to ethnic conflict have been seen since the late 1700s [8], but the latest clashes resulted in the largest migration yet, with an estimated 700,000 people fleeing to Bangladesh since August 2017. 


\section{B. Bangladesh's Role}

Kiragu et al. [9] report that Bangladesh is already an overpopulated nation, with most of its people living in poverty, not to mention they are vulnerable to the harsh effects of frequent natural disasters and climate change that the country is ill-equipped to deal with. Despite this, it is one of the fastest growing countries in terms of economic progress and social development. Even though Bangladesh is identified as a democratic republic, the ruling Awami League party, led by the prime minister Sheikh Hasina, has controversially maintained power since 2009.

Bangladesh and the Rakhine State of Myanmar are separated by the Naf river, which the Rohingya use as a route to travel to Bangladesh. Bangladesh has no system in place for refugee status determination and is not a signatory member of the UN's 1951 Refugee Convention or the 1967 Refugee Status Protocol. Nevertheless, it is obligated to give legal protection to refugees and asylum seekers within its borders due to being involved with major human rights groups, besides being a member of the UNHCR Executive Committee since 1995 [10].

\section{The Daily Star}

The Daily Star identifies itself as a non-partisan, private, and independent news agency, asserts its ethical, non-discriminatory, and socially responsible values, and supports a democratic system of government. The following quote gives us a good idea of its objectives:

"Being well aware of its social responsibilities and duties, the newspaper works to ensure human rights to all, remove gender discrimination, advocate rule of law, press freedom, transparency and accountability in the administration and in the world of trade and industry and above all to uphold national interests" [11].

\section{Research Objective and Question}

Bangladesh, being the first country of asylum that the Rohingya head to, has been chosen in order to study how one of its most popular news media, The Daily Star, reports the issue online. The objective of this research is to investigate how key social actors are represented by The Daily Star in relation to the 2017 Rohingya crisis. In line with the objective, the research question this paper intends to answer is:

RQ: How does The Daily Star represent the main social actors in the context of the 2017 Rohingya crisis?

\section{LITERATURE REVIEW}

This chapter reviews Mutua's [2] SVS framework that guides this research, followed by literature that is relevant to the study.

\section{A. The Savage-Victim-Savior (SVS) Paradigm}

"The subtext of human rights is a grand narrative hidden in the seemingly neutral and universal language of the corpus" [2]. Mutua theorizes about the prevailing metaphors of savage, victim, and savior that run through most human rights discourses, and details how these representations can be limiting and problematic. Dominant human rights discourse, he says, has been shaped into its current conception by Eurocentric norms and ideals. The influence has been so far-reaching that global perceptions of human rights are either defined by or forced to be defined by Western and European standards as a result of being impressed by powerful countries, their foreign policies and diplomatic efforts, and more importantly, INGOs. He explains how 'Third World' countries or developing countries adopt the human rights corpus along with the Western assertion that democracy is the best form of government.

SVS is a compound metaphor whose three components can also stand alone as individual metaphors. The metaphor of the savage within the human rights narrative is built on the premise that the state, mostly an authoritarian one, is evil, hindering progress and challenging freedom.

Human rights literature typically presents victims as innocents who are subjected to abuses like genocide, denial of rights, detention, and racial, religious, or gender discrimination etc. "by the state, its agents, or pursuant to an offensive cultural or political practice" [2]. One of the most defining characteristics of victims- a problematic one according to Mutua- is that they're helpless, powerless, and defenseless against the abuses by the state or culture. The same narratives also usually paint victims as crowds of nameless and desperate people who are mostly uneducated, infirm, too old or too young, sickly, destitute, and starving. "Many of them are women and children twice victimized because of their gender and age" [2]. This language in human rights reports, Mutua says, indicates a cry for help or external intervention to save the victims. These strategies, used to construct the victim as pitiable and sympathetic, help solidify outrage towards the victimizer, who is also the savage.

Saviors can include a range of actors from governmental, non-governmental, and intergovernmental levels, working to 'redeem' non-liberal and non-European societies from human rights violations. The $\mathrm{UN}$ is globally recognized as one such 'savior.' INGOs are also agents of the human rights movement. Most INGOs in Third World countries are influenced by "political, social, and economic models of the West" [2].

Mutua asserts that the human rights project is a specialized endeavor whose main aim is to spread and legitimize liberal democracy in non-Western countries. This is attested by the fact that most Third World NGOs have adopted Western concepts surrounding human rights in order to identify rights violations within their own societies and have accepted human rights norms as part and parcel of democratic government. Mutua does not object to human rights advocacy but claims that the corpus needs a more well-rounded definition of rights and cross-cultural contribution towards the delineation of those rights, to replace the West-leaning representation it currently has which paints most non-Western cultures as savage.

\section{B. Representation of Refugees and Asylum Seekers in Media}

Some key themes have been found to consistently recur across a range of countries and events in the representation of RAS [12]. These groups have been constructed simultaneously as victims, invaders, and threats. Some common labels attached to them are 'illegal,' 'illegitimate,' 
'criminal,' and 'burden,' among others [13].

RAS are most often constructed within discourses of securitization, economization, and victimization, embodying mostly negative attitudes [14]-[18]. The victimization frame can be problematic when RAS are depicted as helpless sufferers who are wholly reliant on external aid [19], by implying that they are burdens.

The conflation of categories related to RASIM is also seen in news [14], [20], [21], and can misinform the public about their situations. Metaphors have been studied extensively to explore how they function in discourse surrounding RAS [22]-[24]. Diachronic research has studied how coverage changes with time and how representations evolve [21], [25], [26].

Significant cross-country research has compared how coverage differs by location [25], [27], [28]. Studies have also found that voice is mostly given to politicians while RAS voices are absent; this disempowers RAS by removing their agency [14], [29], [30]. News media appear to differ in coverage when RAS are differently conceptualized, depending on geographical, political, or historical considerations [14], [31], [33]. A significant relationship has been found between media representations and public attitudes about RAS [23], [34], [35].

Corpus Assisted Discourse Studies (CADS) has been used to study discourse on RASIM in fundamental works [12], [36], [37], as well as recent ones [27], [38]-[40].

\section{Representation of the Rohingya in Media}

Only a few articles have been found on media representation of the Rohingya [41]-[43].

Brooten [41] carried out textual analyses on a series of Pulitzer Prize-winning Reuters reports on the Rohingya from 2013, and alternately on a series of online posts from transnational media. She found that in Reuters reports, Rohingya Muslims were primarily constructed as victims of injustice, hatred, and violence in detailed accounts of atrocities and human rights abuses against them. Burma's Buddhist public, alongside their monks and government forces, were depicted as savages. Regional governments like Malaysia, India, and Thailand were also portrayed within this frame, as nations that do not recognize refugees, that abuse and deport them, or extort and smuggle them. Multiple saviors were constructed in the Reuters articles, including the UN, the US, and Reuters reporters. Alternative media, however, challenged this savior frame Reuters constructed for itself by revealing the agency's inaction and silence over the lawsuit against two Thailand based bloggers by the Royal Thai Navy for quoting excerpts from the Reuters articles.

Brooten et al. [42] analyzed text and images to compare how the New York Times, the Inter Press Services, and the 'Rohingya Community' page on Facebook constructed the 2012 conflict in the Arakan State between Buddhists and Rohingya Muslims. The Facebook page used language and mostly images to construct violent victimization of the Rohingya. It constructed Rakhine Buddhists, the Burmese military forces, and even Bangladeshi officials as savages within the savage-victim-savior framework, while some metaphorical savages were genocide, racism, oppression, killing, and global silence. The international community, the UN, the UNHCR, some Muslim groups, and relief workers were depicted as saviors, with metaphorical saviors being justice, democracy, and freedom, among others. The NYT constructed the Rohingya, Burma's reform process, and investment in the country as victims. The latter two were conditional victims, being potential saviors given foreign intervention were to take place, preferably being directed by the US, which was thus constructed as a savior. The IPS constructed the Rohingya Muslims and Rakhine Buddhists as victims of the state and its strict policies, which were savages within the SVS framework. Media and investment were also constructed by the IPS as savages, with the latter contradicting the NYT representation of investment as a savior.

\section{Literature Gap}

Despite Asia's having the largest number of displaced people, studies on their representation in Asian media are scarce. Moreover, despite searching extensively online, studies that explored media representation of refugees in the Bangladeshi context were hard to trace. This study intends to address the gap in research by looking at how Bangladeshi online news media constructs the Rohingya and other relevant social actors. Findings are expected to shed light on how media representation in a non-Western country compares with dominant Western media representation. Since literature on the Rohingya is also lacking, this investigation would reveal how the representation of Rohingya refugees fits into the global picture of RAS representation in media discourse.

\section{Methodology}

This chapter proposes and justifies the methodology adopted for the study, besides detailing the data collection and analysis procedures.

\section{A. Conceptual Background}

The multidisciplinary CADS approach that combines quantitative and qualitative methods adopted from Corpus Linguistics and Discourse Analysis has many benefits. Both utilize similar theoretical bases while focusing on the use of language in real life. This study conceptualizes discourse according to Foucault's [44] definition, as 'practices which systematically form the objects of which they speak.' Corpus Linguistics involves the analysis of corpora made up of thousands of text fragments, while Discourse Analysis is more concerned with thoroughly analyzing smaller extracts of whole texts. Baker et al. [12] argue that the fusion of the two make for 'a useful methodological synergy' and 'co-penetration.'

The current study looks to quantitative corpus evidence to reveal entry points into the data for qualitative exploration. This process of integrating quantitative and qualitative techniques, termed 'triangulation' in CADS, has been proposed and exemplified by several scholars [12], [45], [46] in response to criticism that critical discourse research can be biased in its selection of data for analysis, arguing that the methodological synergy leads to analysis being more thorough because it involves the whole dataset, and hence ensures that interpretations are more robust and findings more valid [12]. Details about the methods follow. 


\section{B. Analytical Background}

Corpus Linguistics uses analytical tools that calculate frequency, keywords, collocation, and concordance in a corpus that either already exists, like the British National Corpus (BNC), or is custom built to suit the purposes of an investigation. The latter has been done for this research, and the analytical tools most relevant to it will now be explained with reference to AntConc 3.5.7.

The 'Collocation' tool generates a list of the words that appear most frequently within a span of a few words to the left and right of the search item. Significance of collocation is an important consideration here; Mutual Information (MI) calculates the strength and T-score calculates the certainty of collocation between a node word and its collocate [47], [48]. Mautner [45] recommends using both measures in conjunction in order to identify salient collocates. The 'Concordance' tool generates key word in context (KWIC) lines, showing each instance of a search term surrounded by its immediate co-text to facilitate qualitative analysis.

The socio-semantic approach to social actor representation proposed for discourse analysis by Van Leeuwen [49], [50] will be used to analyze the data qualitatively. Representations of social actors become clearer once socio-semantic categories can be linked with their linguistic realizations. This categorization is held to be the 'starting point in discourse analysis' [13]. Some relevant categories are activation, passivation, assimilation, and collectivization.

To sum up, CADS is advantageous because findings revealed by automatically examining large amounts of text are arguably more empirical, generalizable, and replicable than those attained by manually studying small numbers of text. The risk of researcher bias, a criticism often addressed to discourse analysts, is also greatly reduced, as there is more objectivity involved in CADS than in DA or CDA alone, since corpus results guide qualitative analysis.

\section{Data Collection}

To create the corpus, 406 articles, with a total of 122132 words, spanning a year were collected from The Daily Star's online archives if they were found to report the Rohingya crisis. The time period determined for analysis was from August 2017 to August 2018; the most recent refugee migration to Bangladesh started at the end of August 2017, prompted by the worsening of internal conflict and violence in the Rakhine State.

The corpus includes online articles specified by bylines reading 'Star Online Report.' The Daily Star archives its articles using tags, and so when the search term 'Rohingya' was used, the tag 'Rohingya crisis' came up as a suggestion which, when clicked, opened up a chronological archive of all relevant articles, including some unrelated ones. The latter kind were removed from the selection, along with articles that recurred and those that had been sourced from external news agencies like Reuters, AP, etc., after scanning through every article collected. Corpus articles were downloaded and saved as text files, automatically and manually removing hyperlinks, pictures, and captions- because the study focuses on text only, and headlines and subheadings- to minimize repetition in the data.

\section{A. Data Analysis}

The corpus analysis software AntConc (version 3.5.7) was chosen because it is a free and efficient tool for computational analysis of large corpora. A wordlist analysis was initially done once the corpus was loaded on AntConc 3.5.7. As the words 'Rohingya,' 'Myanmar,' 'Bangladesh,' were found to be the topmost frequent nouns, it was decided to explore the constructions of these social actors. The next step was exploring collocates and concordances; Baker [51] says these tools reveal the most information about representation in media. Searches were run using threshold collocation measures of 3 for MI and 5 for T-score [45], and words with a minimum joint frequency of 5 that co-occurred in the two collocate lists were noted for further analysis. Using '*' after a key term like 'Rohingya' included variations of the term, like 'Rohingya' and 'Rohingyas' in analyses. Analyzing concordance lines of selected collocates using Van Leeuwen's [49-50] social actor model helped identify discourses and understand how the main social actors were represented.

\section{FINDINGS AND DISCUSSION}

This chapter summarizes the important findings from the data analysis, discussing them with reference to past literature and the background of the study.

\section{B. Rohingya}

The term 'Rohingya*' was the most frequent content word in the corpus, appearing 1950 times. Concordance analysis showed that the Rohingya were constructed largely as victims of a humanitarian crisis, 'fleeing' or 'escaping' Myanmar. What is clear in the dataset is the frequent use of numbers in relation to the Rohingya 'coming to,' 'entering,' or 'seeking shelter' in Bangladesh. This, as we already know from the literature review (see Chapter 2), is a common feature of media discourse on RASIM. The number of Rohingya entering Bangladesh varies significantly among news reports. Phrases like 'tens of thousands' and 'hundreds of thousands' can be misleading because of how vague they are. Van Leeuwen [49] identifies this quantification as assimilation of social actors. Statistics are frequently used to report the numbers of 'displaced' Rohingya fleeing Myanmar, seeking shelter in Bangladesh, and/or facing various difficulties. The quantification brings attention to the sheer number of people bring victimized by Myanmar, but at the same time serves to raise concern over these large numbers entering Bangladesh. The Rohingya are also collectivized in phrases like 'Rohingya refugees,' Rohingya people,' 'Rohingya Muslims,' and 'Rohingya women and children.' This kind of reporting frames the Rohingya as a homogenous body of victims. For example,

a) "more than 500,000 newly arrived Rohingya refugees are now living in dire conditions in Bangladesh's Cox Bazar" [52].

b) "Nearly 700,000 people, mostly Rohingya women and children, have fled violence in Rakhine State, Myanmar" [53]. 
The above examples show a few ways in which the Rohingya are constructed as victims through a discourse of 'tragedy,' by depicting them as a homogenous group undergoing suffering and injustice in Myanmar. Women and children are highlighted, unlike Rohingya men, which serves to intensify the representation of the minority group as helpless by focusing on its weaker members. Mutua [2] says this enhances the vulnerable condition of victims. The victim image is reinforced by the observation that the Rohingya are not given a voice in the news reports. Concordance analysis of the word 'said,' which collocates significantly with 'Rohingya*,' shows that nearly all occurrences involve statements or opinions by authority figures like the Bangladeshi Prime Minister, Bangladeshi Security officials, IOM, and the UN etc. By not including the voices of the Rohingya, The Daily Star removes their agency and renders them powerless.

Rohingya repatriation to Myanmar is a salient topic. Two important points noticed are the grammatical form of 'repatriate' and the absence of Rohingya voices in the discourse around their 'repatriation.' The use of the noun 'repatriation' and gerund 'repatriating' eliminates the need to specify actors who want it to happen, and the lack of Rohingya voices removes their agency and subjects them to control by more powerful actors.

\section{Bangladesh}

The term 'Bangladesh' is seen 1130 times in the corpus. Bangladesh appears as the goal [49-50] of the Rohingya who are presented as 'fleeing,' 'entering,' or 'crossing into' the country to escape 'violence,' 'ethnic cleansing,' and 'persecution.'

The use of the word 'sheltered,' noticed among the sorted concordances, implies that the Rohingya are protected and safe in Bangladesh as opposed to the country they have 'fled' or 'escaped' from, for example,

a) "Bangladesh has given shelter to the displaced Rohingya people on humanitarian ground after they fled persecution and atrocities by Myanmar army" [54].

b) “The United States has highly appreciated Bangladesh's approach to provide temporary shelter to Rohingya refugees who have fled persecution in Myanmar" [55].

c) "She also appreciated Bangladesh, particularly Prime Minister Sheikh Hasina, for taking the burden of giving shelter to more than one million displaced Rohingyas in Bangladesh, who fled persecution in Rakhine state of Myanmar" [56].

A number of observations are made from the above examples. The reporting contrasts Bangladesh with Myanmar, with the latter as the violent actor abusing the Rohingya, and the former as the benevolent social actor helping the Rohingya on 'humanitarian' grounds (example a). Bangladesh's actions being appreciated by authority figures (example b) lends more strength to the positive representation of Bangladesh and displays a 'sense of consensus among experts' [49]. In example c, the process of nominalizing the Rohingya as a burden is attributed to another authority figure. This constructs the Rohingya as a strain on Bangladesh while at the same time positively representing Bangladesh as sheltering the Rohingya despite not being equipped to do so. The Rohingya are constructed as beneficiaries of 'shelter' given by Bangladesh.

The representation overall constructs Bangladesh as a savior in the corpus. The image, however, is challenged upon further analysis. Example $b$ above indicates that the 'sheltering' is a temporary arrangement. Section 4.1 shows that 'repatriation' is a salient collocate of 'Rohingya*.' The word 'return' is also a salient collocate. While the words 'dignified,' 'safe,' and 'sustainable' are seen to modify both 'repatriation' and 'return' of the Rohingya in concordances, 'repatriation' is further modified by adjectives like 'early,' 'fast' 'immediate,' and 'speedy,' demonstrating rush or urgency on the part of Bangladesh. Thus, we see that there are caveats to the humanitarian response by Bangladesh. For instance, shelter is provided with the expectation that the Rohingya will be repatriated to Myanmar as soon as possible,

a) "Bangladesh is sheltering the Rohingya refugees on humanitarian grounds and Myanmar will have to take back their citizens, Maya said" [57].

and that they will be respectful towards the land that has taken them in on 'humanitarian grounds,'

b) "'Hasan, also a lawmaker of the ruling Awami League, said the government has given shelter to Rohingya refugees on humanitarian ground. "But we cannot allow them to destroy our environment," he added" [58].

In spite of this, Bangladesh is still largely constructed as the savior in The Daily Star corpus.

\section{Myanmar}

'Myanmar' occurs 1318 times in the corpus. Words concerning state, security, and violence appear to occur frequently around Myanmar. Analyzing the expanded concordances of some of these collocates reveals that Myanmar is largely represented within a discourse of power abuse. 'Myanmar' pre-modifies 'army,' 'military,' 'security forces,' 'government,' and 'authorities,' constructing social actors who are collectivized and activated in material processes that involve attacks on the Rohingya, for example,

a) "The systematic acts against the Rohingyas by the Myanmar security forces constitute a serious and blatant violation of international law" [59].

b) "the United States Holocaust Memorial Museum documented Myanmar Army-led massacres, mass gang-rapes, and arson attacks against Rohingya" [60].

c) "The Myanmar authorities also continue to confine more than 120,000 Rohingya to dozens of internment camps" [60].

d) "The aftermath of the ferocious Myanmar military action has led to hundreds of innocent civilian people being killed" [61].

e) "Rania Al-Abdullah today blamed Myanmar government for carrying out ethnic cleansing of Rohingya Muslims" [62].

Myanmar is clearly depicted as the savage in the corpus. More specifically, the government and authorities are held responsible for the Rohingyas' situation, and 'pressured' and 
'called upon,' not just by Bangladesh, but by other authority figures as well, to resolve the issue and 'take back' the Rohingya. For example,

a) "Malaysia and other Asean countries will jointly create pressure on Myanmar government to speed repatriation of Rohingya people who fled persecution in Myanmar" [63].

b) "We are calling upon the Myanmar authorities to act to end the violence and fill up to their commitment to fully implement the recommendations" [64].

The coverage constructs Myanmar as the 'savage' according to Mutua's [2] SVS framework. Thus, Myanmar is mostly negatively represented within a discourse of power abuse in The Daily Star through frequent collectivization with respect to its representative army, military, security forces, government, and authorities. The negative representation of the Myanmar government stands in contrast to the positive representation of the Bangladeshi government by The Daily Star, for example,

a) "Ambassador to Turkey thanked the Bangladesh government for hosting a big number of the Rohingya refugees" [65].

b) "Addressing the occasion, he appreciated the Bangladesh government for its effort to deal with the "unprecedented challenges" [66].

Positive in-group and negative other representation is a common finding in RAS related discourse studies. It is usually the minority out-groups that are negatively represented while the host country is represented positively by its media. Here, however, Myanmar is constructed as the negative 'other.' One of The Daily Star's objectives, which is "to uphold national interests," explains the positive representation of Bangladesh.

In the salient topic of repatriation, just as Rohingya voices are absent, so are Myanmar voices. By not including voices from Myanmar, the media serves a similar purpose of removing Myanmar's agency, Thus the discourse is shaped according to The Daily Star's agenda, and perhaps that of the politics it subscribes to.

\section{CONCLUSION}

Just as the patterns observed within media discourse are important, the absences are also important to identify because they can reveal significant information about social actors. The absence of Rohingya and Myanmar voices in the data imply that the coverage prioritizes Bangladeshi representation. Based on the background information we have on The Daily Star's being pro-democracy and keen about human rights, we can conclude that it is heavily influenced by the existing human rights corpus and its Eurocentric ideals, indicated by the SVS trope being common to both corpora. The analysis reveals how key social actors were constructed by The Daily Star in the context of the 2017 Rohingya crisis. The representation of Rohingya refugees compares in notable ways with Western media representation of RAS. In Western media, RAS are constructed largely within securitization and economization discourses. In The Daily Star; the Rohingya are constructed as economic burdens in a few instances. However, while the West is expected to provide aid to RAS in host countries, Bangladesh is too weak economically to afford this without foreign aid, which it has gotten steadily and sufficiently since the start of the crisis. The predominant representation of the Rohingya is as victims rather than threats. Other studies in Asia have also found RAS constructed mostly as victims by host countries, while in the West, their construction as threats is more prominent. RAS' Muslim identities are often seen to be targeted negatively in Western media representations, usually in the form of an 'us' versus 'them' dichotomy contrasting the Christian majority West with Muslim minorities; this pattern was inexistent in The Daily Star, most likely because Bangladesh itself is a majority Muslim country.

This article addresses a gap in the literature on RAS by exploring how Bangladesh constructs the Rohingya and other relevant social actors. Due to space constraint, only the important findings are detailed. Further research is encouraged to explore how media discourse may influence public perception of the Rohingya in Bangladesh.

\section{REFERENCES}

[1] United Nations High Commissioner for Refugees. (2017). Global Trends: Forced Displacement in 2016. [Online]. Available: https://www.unhcr.org/5943e8a34.pdf

[2] M. Makau, "Savages, victims and saviors: The metaphor of human rights," Harvard International Law Journal, vol. 42, no. 1, pp. 201-245, 2001.

[3] P. Green, "Islamophobia: Burma's racist fault-line," Race and Class, vol. 55, no. 2, pp. 93-98, 2013.

[4] P. Oberoi, Exile and Belonging: Refugees and State Policy in South Asia, Oxford: Oxford University Press, 2006.

[5] Human Rights Watch, "All you can do is pray," Crimes against Humanity and Ethnic Cleansing of Rohingya Muslims in Burma's Arakan State, New York: Human Rights Watch, 2013.

[6] Human Rights Watch, Burma the Rohingya Muslims Ending a Cycle of Exodus, New York, NY: Author, 1996.

[7] M. Zarni and A. Cowley, "The slow-burning genocide of Myanmar'S Rohingya," Pacific Rim Law \& Policy Journal, vol. 23, pp. 683-754, 2014.

[8] A. K. M. A. Ullah, "Rohingya crisis in Myanmar: Seeking justice for the "Stateless," Journal of Contemporary Criminal Justice, vol. 30, no. 3, pp. 285-201, 2016.

[9] Kiragu et al. (2011). States of denial: A review of UNHCR's response to the protracted situation of stateless Rohingya refugees in Bangladesh, United Nations High Commissioner for Refugees, Policy Development and Evaluation Service. Available: http://www.unhcr.org/4ee754c19.pdf

[10] U. Rahman, "The Rohingya refugee: A security dilemma for Bangladesh," Journal of Immigrant and Refugee Studies, vol. 8, no. 2, 233-239, 2010.

[11] About us (2019, January 23). The Daily Star. [Online]. Available: https://www.thedailystar.net/about-us

[12] P. Baker, C. Gabrielatos, M. Khosravinik, M. Krzyżanowski, T. Mcenery, and R. Wodak, "A useful methodological synergy? Combining critical discourse analysis and corpus linguistics to examine discourses of refugees and asylum seekers in the UK press,' Discourse and Society, vol. 19, no. 3, pp. 273-306, 2008.

[13] M. KhosraviNik, "The representation of refugees, asylum seekers and immigrants in British newspapers during the Balkan conflict (1999) and the British general election," Discourse and Society, vol. 20, no. 4, pp. 477-498, 2019

[14] G. Philo, E. Briant, and P. Donald, "The role of the press in the war on asylum," Race \& Class, vol. 55, no. 2, pp. 28-41, 2013.

[15] L. Gilbert, "The discursive production of a mexican refugee crisis in canadian media and policy," Journal of Ethnic and Migration Studies, vol. 39 , no. 5 , pp. 827-843, 2013.

[16] Z. M. Don and C. Lee, "Representing immigrants as illegals, threats and victims in Malaysia: Elite voices in the media," Discourse \& Society, vol. 25, no. 6, pp. 687-705, 2014.

[17] E. Greussing and H. G. Boomgaarden, "Shifting the refugee narrative? An automated frame analysis of Europe's 2015 refugee crisis," Journal of Ethnic and Migration Studies, vol. 43, no. 11, pp. 1749-1774, 2017. 
[18] B. Holzberg, K. Kolbe, and R. Zaborowski. (2018). Figures of Crisis: The Delineation of (Un)Deserving Refugees in the German Media. [Online]. Available: https://doi.org/10.1177/0022487108324554

[19] L. Chouliaraki, The Ironic Spectator: Solidarity in the Age of Post-Humanitarianism, Cambridge, UK: Polity Press, 2016.

[20] S. Bennett, J. T. Wal, A. Lipiński, M. Fabiszak, and M. Krzyżanowski, "The representation of third-country nationals in European news discourse," Journalism Practice, 2013.

[21] S. Goodman, A. Sirriyeh, and S. Mcmahon, "The evolving (re)categorisations of refugees throughout the "refugee/migrant crisis," Journal of Community \& Applied Social Psychology, vol. 27, no. 2, pp. 105-114, 2017.

[22] R. Z. Abid, S. A. Manan, and Z. A. Rahman, "A flood of Syrians has slowed to a trickle': The use of metaphors in the representation of Syrian refugees in the online media news reports of host and non-host countries," Discourse \& Communication, vol. 11, no. 2, pp. 121-140, 2017.

[23] L. Arcimaviciene and S. H. Baglama. (2018). Migration, metaphor and myth in media representations: The ideological dichotomy of "them" and "Us." SAGE Open. [Online]. Available: https://doi.org/10.1177/2158244018768657

[24] L. Lams, "Discursive constructions of the summer 2015 refugee crisis: A comparative analysis of French, Dutch, Belgian francophone and British centre-of-right press narratives," Journal of Applied Journalism \& Media Studies, vol. 7, no. 1, pp. 103-127, 2018.

[25] T. Müller, "Constructing cultural borders: Depictions of Muslim refugees in British and German media," Zeitschrift Für Vergleichende Politikwissenschaft, vol.12, no. 1, pp. 263-277, 2017.

[26] J. Tong and L. Zuo. (2018). Othering the European Union through constructing moral panics over 'im/migrant(s)' in the coverage of migration in three British newspapers. [Online]. Available: https://doi.org/10.1177/1748048518802237

[27] C. Taylor, "Investigating the representation of migrants in the UK and Italian press: A cross-linguistic corpus-assisted discourse analysis," International Journal of Corpus Linguistics, vol. 19, no. 3 , pp. 368-400, 2014

[28] J. F. Hovden, H. Mjelde, and J. Gripsrud, "The Syrian refugee crisis in Scandinavian newspapers," Communications, vol. 43, no. 3, pp. 325-356, 2018.

[29] A. Elsamni, "Framing Arab refugees in global news," SSRN Electronic Journal, 2016.

[30] L. Chouliaraki and R. Zaborowski, "Voice and community in the 2015 refugee crisis: A content analysis of news coverage in eight European countries," International Communication Gazette, vol.79, no. 6-7, pp 613-635, 2017.

[31] E. A. Ehmer and A. Kothari, "Coverage of burmese refugees in Indiana news media: An analysis of textual and visual frames," Journalism, vol. 19, no. 11, pp. 1552-1569, 2016.

[32] A. Lawlor and E. Tolley. (2017). Deciding who's Legitimate: News media framing of immigrants and refugees. [Online]. Available: https://ijoc.org/index.php/ijoc/article/view/6273

[33] R. D. Cock, S. Mertens, E. Sundin, L. Lams, V. Mistiaen, W. Joris, and L. D'Haenens, "Refugees in the news: Comparing Belgian and Swedish newspaper coverage of the European refugee situation during summer 2015," Communications, vol. 43, no.3, pp. 301-323, 2018

[34] V. M. Esses, S. Medianu, and A. S. Lawson, "Uncertainty, threat, and the role of the media in promoting the dehumanization of immigrant and refugees," Journal of Social Issues, vol. 69, no. 3, pp. 518-536, 2013.

[35] S. Blinder and W. L. Allen, "Constructing Immigrants: Portrayals of migrant groups in British national newspapers," International Migration Review, vol. 50, no.1, pp. 3-40, 2016.

[36] P. Baker and P. McEnery, "A corpus-based approach to discourses of refugees and asylum seekers in UN and newspaper texts," Journal of Language and Politics, vol. 4, no. 2, pp. 197-226, 2015.

[37] C. Gabrielatos and P. Baker, "Fleeing, sneaking, flooding," Journal of English Linguistics, vol. 36, no. 1, pp. 5-38, 2008.

[38] S. Fotopoulos and M. Kaimaklioti, "Media discourse on the refugee crisis: On what have the Greek, German and British press focused? European View," vol. 15, no. 2, pp. 265-279, 2016.

[39] A. S. Haider and S. Olimy, "The representation of Laji'een (refugees) and Muhajireen (migrants) in the headlines of Jordan news agency (PETRA)," International Journal for the Semiotics of Law - Revue Internationale De Sémiotique Juridique, 2018.

[40] I. Efe, "A corpus-driven analysis of representations of Syrian asylum seekers in the Turkish press 2011-2016," Discourse \& Communication, 2018.
[41] L. Brooten, "Blind spots in human rights coverage: Framing violence against the Rohingya in Myanmar/Burma," Popular Communication, vol. 13 , no. 2 , pp. 132-144, 2015.

[42] L. Brooten, S. I. Ashraf, and N. A. Akinro, "Traumatized victims and mutilated bodies: Human rights and the 'politics of immediation' in the Rohingya crisis of Burma/Myanmar," International Communication Gazette, vol. 77, no. 8, pp. 717-734, 2015.

[43] N. Afzal, "Elements of pathos and media framing as scientific discourse: A newspaper perspective on the Rohingya crisis," International Journal of Advanced and Applied Sciences, vol. 3, no. 10 pp. 89-99, 2016.

[44] M. Foucault, The Archaeology of Knowledge, London: Tavistock. Translated by A. M. Sherdidan Smith, 1972.

[45] G. Mautner, "Mining large corpora for social information: The case of elderly," Language in Society, 2007.

[46] C. R. Caldas-Coulthard and R. Moon, "Curvy, hunky, kinky': Using corpora as tools for critical analysis," Discourse and Society, vol. 21, no. 2, pp. 99-133, 2010.

[47] S. Hunston, Corpora Applied Linguistics, Cambridge: Cambridge University Press, 2002

[48] T. Mcenery and A. Wilson, Corpus linguistics: An Introduction, Edinburgh: Edinburgh University Press, 2001.

[49] T. V. Leeuwen, "The representation of social actors in discourse," Text and Practices: Readings in Critical Discourse Analysis, pp. 32-70, London: Routledge, 1996.

[50] T. V. Leeuwen, Discourse and Practice: New Tools for Critical Discourse Analysis, Oxford: Oxford University Press, 2008.

[51] P. Baker, Using Corpora in Discourse Analysis, London: Continuum, 2006.

[52] UN Migration agency head issues personal appeala to support Rohingya refugees [Online]. Available: https://www.thedailystar.net/rohingya-crisis/united-nations-migrationagency-head-pleas-ending-rohingya-crisis-1471915

[53] Myanmar's BGP asks Rohingyas at Tombru to leave no-man's land. [Online]. Available: https://www.thedailystar.net/rohingya-crisis/myanmar-bgp-asks-rohin gyas-to-leave-no-mans-land-bandarban-bangladesh-1578562

[54] Rohingya crisis a 'humanitarian disaster' (2017, October 19). The Daily Star. [Online]. Available: https://www.thedailystar.net/rohingya-crisis/border-guard-bangladesh -bgb-chief-terms-myanmar-rohingya-crisis-a-humanitarian-disaster-1 478827

[55] US lauds Bangladesh's role over Rohingya issue. The Daily Star [Online]. Available: https://www.thedailystar.net/country/us-lauds-bangladesh-role-over-r ohingya-issue-crisis-1471378

[56] Open your hearts, treat Rohingya children as your own: Priyanka. (2018, May 24). [Online]. Available: https://www.thedailystar.net/rohingya-crisis/bollywood-actress-priyan ka-chopra-rohingya-children-living-in-vulnerable-condition-at-refuge e-camps-in-coxs-bazar-the-world-needs-care-1580920

[57] All Rohingya refugees to be under biometric registration in 60 days (2017, September 21). [Online]. Available: https://www.thedailystar.net/world/rohingya-crisis/all-refugees-in-ban gladesh-be-under-biometric-registration-60-days-1465432

[58] Rohingyas damage forest worth Tk 151 crore in Cox's Bazar' (2017, October 11), The Daily Star. [Online]. Available: https://www.thedailystar.net/rohingya-crisis/bangladesh-parliamentar y-standing-committee-forest-environment-myanmar-rohingyas-damag e-forest-coxs-bazar-1474405

[59] OIC seeks international support to resolve Rohingya crisis (2018, May 6). The Daily Star. [Online]. Available: https://www.thedailystar.net/rohingya-crisis/oic-condemns-atrocitiesmyanmar-rohingyas-refugees- 1572343

[60] Fortify Rights urges UNSC to refer genocide in Myanmar to ICC (2018, February 13). [Online]. Available: https://www.thedailystar.net/rohingya-crisis/fortify-rights-urges-unscrefer-genocide-myanmar-icc-1534174

[61] 114 int'l orgs, 32 individuals urge Myanmar to protect civilians' rights in Rakhine. [Online].

Available: https://www.thedailystar.net/rohingya-crisis/114-international-organis ations-32-individuals-urge-myanmar-to-protect-civilians-rights- 15050 50

[62] Myanmar carries out Rohingya cleansing: Jordan Queen Rania [Online]. Available: https://www.thedailystar.net/rohingya-crisis/jordan-queen-rania-al-ab dullah-says-myanmar-carries-out-rohingya-ethnic-cleansing-1480603

[63] 'Malaysia to create pressure for Rohingya repatriation'. [Online] Available: 
https://www.thedailystar.net/rohingya-crisis/malaysia-will-create-pres sure-rohingyas-repatriation-to-myanmar-1477150

[64] Rohingyas want safety, equal rights before repatriation: Oxfam. The Daily Star. [Online]. Available: https://www.thedailystar.net/rohingya-crisis/rohingyas-in-bangladeshcamps-want-safety-equal-rights-before-repatriation-to-myanmar-rakhi ne-state-oxfam-report-1507366

[65] Turkey thanks Bangladesh for hosting Rohingya refugees. The Daily Star. [Online].

Available: https://www.thedailystar.net/world/south-asia/turkey-thanks-banglade sh-hosting-rohingya-refugees-1462993

[66] Rohingya aid from India, Morocco, Indonesia arrives. [Online]. Available:

https://www.thedailystar.net/country/morocco-sends-rohingya-aid-ind ian-relief-arrive-bangladesh-myanmar-1462063

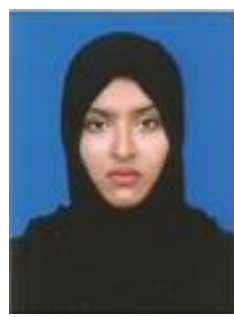

Sharufatun Nahar was born in Muscat, Oman, in 1993, but is of Bangladeshi origin. After completing her A-levels in Oman, she moved to Bangladesh to pursue a bachelors in English Language and Literature from the University of Science and Technology, Chittagong (USTC), graduating at the top of her class with first-class honours in 2015. She is currently pursuing her masters in linguistics at the University of Malaya in Kuala Lumpur. Her area of research is discourse analysis.

Ms. Nahar is a full-time student, whose research interests within the field of discourse studies include corpus-assisted discourse analysis, media discourse, and political discourse. 